\title{
Alterações hematológicas, bioquímicas, urinárias e histopatológicas na intoxicação natural em bovinos pela samambaia Pteridium aquilnum (L.) Kühn
}

\section{Hematologycal, biochemical, Urinary and histopathological changes in natural intoxication in bovine by bracken fern (Pteridium aquilinum) (L.) Kühn}

\author{
Margarete Kimie Falbo ${ }^{1 *}$; Antônio Carlos Faria dos Reis ${ }^{2}$; \\ Mara Regina Stipp Balarin²; Ana Paula F. R. L. Bracarense²; \\ João Pessoa Araújo Jr. ${ }^{3}$; Werner Okano ${ }^{4}$; Itacir Eloi Sandini ${ }^{5}$
}

Resumo

\begin{abstract}
A hematúria enzoótica é uma doença crônica dos bovinos caracterizada clinicamente por hematúria intermitente que pode ser causada pela samambaia (Pteridium aquilinum) e o vírus da papilomatose. Por meio deste estudo verificamos as alterações clínico-laboratoriais em bovinos, mestiços, fêmeas, naturalmente intoxicados pela samambaia, em propriedades rurais de criação extensiva na região norte do Paraná, durante o período de 6 meses. Os resultados mostraram baixo nível plasmático de cálcio, níveis plasmáticos normais para fósforo e magnésio, aumento da excreção urinária fracionada de cálcio e fósforo. Histopatologicamente foram observadas alterações neoplásicas como papiloma, hemangioma e carcinoma de células transicionais além de metaplasia e hiperplasia na bexiga. Provas de imuno-histoquimica e reação em cadeia pela polimerase (PCR) de cortes parafinados mostraram resultado negativo para o agente viral.

Palavras-chave: Pteridiun aquilinum, samambaia, hematúria enzoótica
\end{abstract}

\begin{abstract}
Enzootic hematuria is a cronic disease of cows clinically characterized by intermittent hematuria that can be caused by bracken fern (Pteridium aquilinum) and the papilomatosis virus. We describe the clinical and laboratorial abnormalities observed during period of 6 months in naturally affect cows extensively raised in the north region of Paraná State. The animals had low concentrations of total calcium, with normal levels phosphorus and magnesium. Fractional excretion of calcium and phosphorus were increased. Metaplasia and hyperplasia in the epithelium as well as papilomas, hemangiomas, and transitional cell carcinomas were observed histopathologically in the urinary bladder. We were unable to demonstrate any viral presence by imunnohistochemistry and polymerase chain reaction (PCR) of paraffin blocks.

Key words: Pteridiun aquilinum, bracken fern, enzootic hematuria
\end{abstract}

1 Profa. Assistente do Depto de Medicina Veterinária, Universidade Estadual do Centro Oeste - PR. Email: margaretefalbo@hotmail.com.

2 Prof. Adj. Dr. do Depto de Medicina Veterinária Preventiva, Universidade Estadual de Londrina-PR.

3 Prof. Dr. do Depto de Microbiologia e Imunologia - Instituto Biociências, UNESP, Botucatu - SP.

4 Prof. MSc. do Depto Medicina Veterinária da Universidade Norte Paranaense- UNOPAR, Arapongas - PR.

5 Prof. Assistente do Depto de Agronomia, Universidade Estadual do Centro Oeste - PR.

* Autor para correspondência. 


\section{Introdução}

A Hematúria Enzoótica bovina (HEB) é uma enfermidade não infecciosa crônica, caracterizada pelo desenvolvimento de lesões hemangiomatosas na parede da bexiga urinária e clinicamente por hematúria intermitente e morte em decorrência da anemia (BLOOD; RADOTITS, 1989). A doença tem sido bservada em várias partes do mundo e em diversos estados do Brasil (BARONI et al., 1978 apud MOURA et al., 1989), sendo associada a ingestão da planta Pteridium aquilinum, vulgarmente conhecida como samambaia (TOKARNIA; DÖBEREINER; SILVA, 1979) e se desenvolve em solos pobres, ácidos, com baixos níveis de cálcio e fósforo (HOPKINS, 1990). Todas as partes da planta contêm o princípio tóxico em forma ativa, sendo o broto a porção mais tóxica de suas partes aéreas (HIRONO; FUSHIMI; MORI, 1973).

Singh, Joshi e Ray (1972) estudaram as alterações hematológicas e bioquímicas de bovinos com Hematúria Enzoótica e verificaram uma considerável redução no hematócrito e hemoglobina com anemia progressiva devido a perda contínua de sangue pela urina. A anemia, segundo Jean-Blain, Gastellu e Bringuier (1987), regride em quinze dias assim que cesse a hematúria. Um moderado grau de linfocitose e neutropenia foi observado, devido a condição inflamatória crônica (SINGH; JOSHI; RAY, 1972) e diminuição nos níveis séricos de cálcio, fósforo (SINGH; JOSHI; RAY, 1972; GHERGARIU; BALE; OROS, 1990), magnésio (GHERGARIU; BALE; OROS, 1990) e aumento da creatinina sérica (SINGH; JOSHI; RAY, 1972).

As análises da urina demonstraram leve proteinúria, aumento da atividade sérica da gamaglutamiltransferase (GGT), da concentração de cálcio e magnésio e excreção normal para o fósforo (GHERGARIU; BALE; OROS, 1990). Segundo Coffman (1980), o rim é o principal órgão modulador da homeostase eletrolítica e a determinação da perda de eletrólitos pela excreção renal assume um grande valor desde que associada ao conhecimento da concentração sérica. Considerando que somente a análise dos níveis de eletrólitos na urina não é um parâmetro confiável, os valores de cálcio, fósforo e creatinina urinária são obtidos para a realização do cálculo da excreção fracionada desses eletrólitos devido ás variações na absorção e excreção de água que dificultam a interpretação devido à extensa variação na concentração de solutos na urina (CAPLE; BOURKET; ELLIST, 1982), ou seja, um grande volume de urina diluída pode apresentar uma maior perda de substâncias em relação a uma urina concentrada de pouco volume (TRAVER, 1976 apud BALARIN, 1990).

A creatinina endógena em bovinos tem a propriedade de ser passivamente filtrada pelos glomérulos e insignificantemente secretada ou reabsorvida pelos túbulos renais, o que faz dela uma substância de eleição para ser utilizada no cálculo da excreção fracionada (NEIGER; HAGE MOSER, 1985). Como a creatinina é produzida a todo o momento pelo metabolismo de energia muscular não há necessidade de injetá-la para medir a excreção fracionada. Dessa forma podemos comparar a excreção fracionada de algum eletrólito com o de creatinina endógena e determinar com razoável precisão a excreção renal desse eletrólito, eliminando da equação o volume urinário (BALARIN, 1990).

Macro e microhematúria são encontrados nos animais com Hematúria Enzoótica, sendo a duração destas alterações variável de um animal a outro (um dia a várias semanas), podendo ser separada por períodos de remissão com duração de semanas a anos (DURÃO; FERREIRA; CABRAL, 1995).

Hopkins (1987), comparando animais com e sem hematúria verificou que $8 \%$ dos animais aparentemente sadios apresentavam hemácias no sedimento urinário, sugerindo que este fato representaria um estágio pré-clínico da Hematúria Enzoótica. Pachauri, Sharma e Joshi (1981) e Hopkins (1986) classificaram os tumores de bexiga de bovinos com hematúria enzoótica em epitelial (carcinoma de células de transição e 
adenocarcinoma) e não epitelial (hemangioma e fibroma). Células tumorais com aparência vacuolada e apresentando corpúsculos de inclusão acidófilos intracitoplasmáticos foram identificadas por Pachauri, Sharma e Joshi (1981), sugerindo o possível envolvimento de agente viral. Yoshikawa e Oyamada (1975) classificaram histologicamente cinqüenta e três casos espontâneos de tumores papilomatosos em bovinos e citam como fator predisponente ao desenvolvimento desse tumor a ingestão da Pteridium aquilinum e a presença do papilomavírus bovino (BPV).

Segundo Campo et al. (1992) e Campo (1997), a função exata do vírus junto com a samambaia e o possível sinergismo entre os fatores virais, químicos e imunológicos na formação do tumor não está bem esclarecido. O BPV-2, através da técnica Southern blotting, tem sido detectado experimentalmente em $69 \%$ de câncer de bexiga e $46 \%$ em casos naturais, sugerindo uma associação entre o BPV e a formação de neoplasias em bexiga. Campo, Jarret e O'Neil (1994) sugerem que os linfócitos circulantes pode ser outro local de latência para o BPV além do epitélio. A imunossupressão e ou trauma físico são suficientes para ativar o papilomavírus latente, mas são necessários os agentes químicos mutagênicos da planta para a progressão maligna da lesão viral.

A hematúria enzoótica é um problema econômico em muitos estados brasileiros e o objetivo deste trabalho foi estudar as alterações orgânicas provocadas pela planta na fase subclínica da doença, através de análises hematológicas e bioquímicas no sangue e urina, verificar as alterações histopatológicas em bexiga presente nesta fase e um possível envolvimento do papilomavírus bovino tipo 2 (BPV 2).

\section{Material e Métodos}

\section{Seleção das propriedades e dos animais}

Foram selecionadas duas propriedades na região norte do estado do Paraná, com presença da samambaia na pastagem. Cento e noventa bovinos, fêmeas, mestiços nelores, adultos, de uma propriedade rural localizada no município de Nova Fátima, foram submetidos ao exame de sedimento urinário e identificados treze animais com microhematúria. Na outra propriedade rural, localizada no município de Sapopema, dos quarenta e sete bovinos fêmeas, mestiços nelores, adultos, que submetidos ao exame de sedimento urinário, foram identificados mais quatorze animais com microhematúria. Foram considerados com microhematúria os animais que apresentavam mais do que 5000 hemácias/ml.

Os animais selecionados, num total de vinte e sete, foram identificados e no período de janeiro a setembro de 1999, foram colhidas cento e quarenta e uma amostras de sangue e urina. Deste total, nove animais desenvolveram hematúria dentre eles seis animais vieram a óbito, um no mês três e cinco animais no mês quatro.

\section{Colheita das amostras e exames clínicos} laboratoriais

Colheita de sangue: foram colhidos de cada animal $15 \mathrm{ml}$ de sangue total por meio da punção da veia jugular, em tubos estéreis contendo anticoagulante conforme descrição abaixo: Hemograma e contagem de plaquetas: foram colhidos $5 \mathrm{ml}$ de sangue em tubos esterilizados contendo o anticoagulante sal di-sódico do ácido diaminotetracético (EDTA) a 10\%, para a realização de hemograma, contagem do número total de plaquetas e cálculo dos índices hematimétricos absolutos, segundo Schalm (1986).

Bioquímicos: foram colhidos $10 \mathrm{ml}$ de sangue em tubos esterilizados contendo o anticoagulante heparina (5.000 UI / ml), submetidos à centrifugação (3.000 rotações por minuto, durante cinco minutos) para obtenção do plasma. Foram realizados os seguintes exames: Creatinina: pelo método picrato alcalino* (Kit Analisa); Uréia: pelo método urease colorimétrica* (Kit Analisa); Cálcio pelo método colorimétrico*(Kit Analisa); Fósforo: pelo método colorimétrico Basques-Lustosa*(Kit Analisa); Magnésio: pelo 
método colorimétrico* (Kit Analisa); e dosagem de fibrinogênio plasmático pelo método do tubo capilar e precipitação a 56 graus Celsius (SCHALM, 1986).

\section{Colheita de urina: foi colhida por micção espontânea}

Urinálise: a urinálise completa foi realizada seguindo a técnica de Addis, citada por Levinson e Mcfate (1969) e Vallada (1981). As amostras com $10 \mathrm{ml}$ de urina foram submetidas ao exame físico que foi constituído pela determinação do volume, cor, aspecto, odor e a densidade aferida pelo refratômetro. O exame químico (proteína, acetona, glicose, pigmentos biliares, sais biliares, urobilinogênio, hemoglobina), realizado através de tiras reagentes $\left(\right.$ Combur Test $\left.{ }^{\circledR}\right)$. Para as análises do sedimento urinário as amostras foram centrifugadas a 1800 rotações por minuto (rpm) durante cinco minutos, em seguida desprezou-se o sobrenadante $(9 \mathrm{ml})$, restando $1 \mathrm{ml}$ de urina mais o sedimento. Realizou-se a homogeneização e o preenchimento da câmara de Neubauer e feita a contagem de hemácias e leucócitos no quadrante central da câmara, com a objetiva de 40.

Para o estabelecimento de um grupo controle e padronização da contagem de hemácias/ml no sedimento urinário, foram selecionados quarenta e um bovinos, mestiços nelores, fêmeas, de uma propriedade isenta de samambaia. Esses animais não apresentaram nenhuma alteração ao exame clínico. A urina foi colhida por micção espontânea.

Análises bioquímicas na urina forma realizadas para determinação dos seguintes exames:

- Creatinina: pelo método picrato alcalino* (Kit Analisa);

- Cálcio: pelo método colorimétrico *(Kit Analisa), com a seguinte modificação: utilizou-se, para a acidificação da urina, uma gota de ácido clorídrico concentrado para cada $1 \mathrm{ml}$ de urina e não para cada $5 \mathrm{ml}$ como propõe o método. Tal procedimento se fez necessário porque o método foi preparado para urina ácida (BALARIN, 1990) e a urina dos bovinos é bastante alcalina.

- Fósforo: pelo método colorimétrico Basqueslustosa* (kit Analisa) com a seguinte modificação: utilizou-se a amostra de urina sem efetivar a diluição proposta pelo método (1:10). Isso se fez necessário devido a baixa concentração desse elemento em uma amostra de urina em relação à amostra de 24 horas que é utilizada em humanos, para qual o método foi preparado (BALARIN, 1990).

Os valores de cálcio, fósforo e creatinina urinária foram obtidos para a realização do cálculo da excreção fracionada desses eletrólitos, segundo método proposto por Coffmann (1980) para eqüinos, utilizando-se a excreção fracionada da creatinina como padrão.

\section{Análise estatística}

Foi realizada análise descritiva, onde foram calculadas a média (X), desvio padrão (s), valor máximo e mínimo (TUKEY, 1977), para cada uma das variáveis no sangue e urina de amostras obtidas dos animais estudados durante os seis meses

\section{Anatomia patológica}

Durante esse período, nove animais desenvolveram macrohematúria, sendo que seis vieram a óbito, os quais foram colhidos às bexigas para análise macro e microscópica. As amostras foram fixadas em formalina tamponada á $10 \%$, incluídas em parafina e os blocos posteriormente cortados em micrótomo com espessura de cinco micrômetros $(5 \mathrm{~mm})$ de espessura. Os cortes foram corados pelo método da hematoxilina-eosina (HE) para o exame histopatológico sob microscopia óptica.

\section{Imuno-histoquímica}

Das lâminas examinadas por microscopia óptica, foram selecionadas aquelas com diagnóstico de 
lesões proliferativas, hiperplásicas ou neoplásicas e submetidas ao método do polímero marcado conjugado com anticorpos secundários (GIMENO, 1997) que foram realizados segundo o kit da Daco Co.(Carpinteria, EUA) utilizando anticorpos primários policlonais antipapilomavírus, produzido em coelhos.

\section{Reação em cadeia pela polimerase (PCR)}

A reação em cadeia pela polimerase foi realizada em tecido de bexiga parafinado, cortados com espessura de nove micrômetros $(9 \mathrm{~mm})$ e então submetidos a técnica de desparafinação, seguida da extração do DNA pelo método Brometo Cetil Trimetil Amônio [CTAB] (MURRAY; THOMPSON, 1980; MANFIOLETTI; SCHNEIDER, 1988).

Foram realizadas como pares de oligonucleotídeos os iniciadores NO1 (5'- TTGCTGCAATGCAACTGCTG3') e NO2 (5'-TCATAGGCACTGGCACGTT-3') que amplificam tanto BPV-1 como o BPV- 2 . A amplificação foi realizada utilizando-se $5 \mu 1$ de PCR buffer ; $1.5 \mu 1$ de $\mathrm{MgCl} 2,0.5 \mu 1$ dNTP mix a $20 \mathrm{mM}$, $1.5 \mu 1$ primer $\mathrm{NO} 1,1.5 \mu 1$ primer $\mathrm{NO} 2,0.25 \mu 1$ de DNA Taq polimerase (GIBCO BRL); $29.75 \mu 1$ de água miliQ e $10 \mu 1$ da amostra para um volume final de $50 \mu \mathrm{L}$. As amostras foram processadas no termociclador, com a seguinte programação: $95^{\circ} \mathrm{C}$ por 5 min., seguidos por 30 ciclos de $96^{\circ} \mathrm{C}$ por $1 \mathrm{~min}$., $53^{\circ} \mathrm{C}$ por $1 \mathrm{~min}$., $72^{\circ} \mathrm{C}$ por $1 \mathrm{~min}$. com uma extensão final a $72^{\circ} \mathrm{C}$ por 5 min. e posterior sfriamento a $4{ }^{\circ} \mathrm{C}$ por tempo indeterminado em cada amplificação (NASIR; McFARLANE; TORRONTEGUI, 1997).

O produto da PCR $(10 \mu 1)$ foi visualizado em gel de agarose a $2 \%$ e corado com brometo de etídio $(0.5 \mu \mathrm{g} / \mathrm{ml})$, utilizando como tampão de Tris- EDTAác. bórico (TEB) 1x, aplicando 80v e 30.7mA durante $1 \mathrm{~h} 30 \mathrm{~min}$. Utilizou-se a água como controle negativo e papiloma cutâneo como controle positivo.

O fragmento de DNA amplificado (312 pares de base) pela PCR, foi identificado pela comparação com marcadores de peso molecular de 50 pares de base (GIBCO BRL).

\section{Resultados}

Hematologia, Bioquímica e Urinálise:

Os resultados, bem como a interpretação da análise estatística das cento e quarenta e uma amostras de sangue, das quais setenta e cinco com microhematúria, dezesseis com macrohematúria e cinqüenta amostras dentro dos parâmetros normais, devido a característica intermitente da doença, estão apresentados nas tabelas 1, 2, 3 e 4 .

\section{Anatomia Patológica}

Seis animais vieram a óbito e destes foram colhidas às bexigas, para exames macro e microscópico.

Macroscopicamente a maioria das bexigas apresentou parede espessada e algumas delas conteúdo urinário hemorrágico, inclusive com a presença de coágulos. Em sua parede interna, foram observadas dobras irregularmente espessa e alterações hemorrágicas (petéquias, equimoses ou amplas hemorragias), isoladas ou múltiplas. Essas lesões hemorrágicas mostraram formas irregulares, localizações variadas e as maiores apresentavam-se elevadas em relação à superfície da mucosa. Formações de aspecto papilomatoso do epitélio da bexiga foram também caracterizadas, mostrando da mesma forma tamanhos e formas distintas, com bases sésseis ou pedunculadas.

Ao microscópio óptico o epitélio transicional mostrou espessura variada, de uma a várias camadas de células, distribuídas em toda extensão da mucosa da bexiga e apresentando invaginações aparentemente sem ramificações. Hiperplasia de epitélio foi um achado freqüente $(66,6 \%)$ neste estudo, ocorrendo na maioria das vezes nas proximidades das invaginações do epitélio. Erosões epiteliais foram verificadas em diferentes pontos da mucosa, enquanto as lesões descamativas celulares do epitélio foram localizadas em áreas de invaginações ou próximas a estas. Formações metaplásicas de tipo epitelial escamoso ou epitelial 
cilíndrico (33,3\%) foram verificadas coincidentemente em bexigas com alterações hiperplásicas.

Lesões inflamatórias localizadas em córion apresentaram-se em forma de nódulos constituídos de células mononucleares, com predomínio de linfócitos, difusos em córion, localizados abaixo do urotélio e neste caso foram verificados elementos dispostos entre as células epiteliais. Infiltrado inflamatório contendo neutrofílos e células mononucleares foram observadas em somente um dos animais examinados. Eosinófilos, em um dos casos, foram identificados disseminados em toda extensão do córion da bexiga.

Crescimentos papilomatosos com excessiva ramificação, revestidos por tecido normal ou hiperplásico, projetavam-se em direção à luz da bexiga. Tais formações apresentavam estroma de tecido conjuntivo relativamente denso com raras formações vasculares evidentes ou de estroma conjuntivo escasso com vascularização evidente.

Formação hemangiomatosa localizada imediatamente abaixo do epitélio e estendendo-se ao córion foi observada em apenas um dos animais. Esta formação neoplásica era constituída de vasos sangüíneos com revestimento endotelial achatado, separada por estreita camada de tecido conjuntivo e sem formação de cápsula delimitante. $\mathrm{O}$ diâmetro destes vasos mostrou uma clara variação. Hemorragias localizadas superficialmente em córion, não foram acompanhadas de lesões ulcerativas do epitélio.

Lesões neoplásicas do epitélio transicional, carcinomas, mostraram alto índice mitótico e suas células infiltravam-se através do córion da bexiga.

\section{Pesquisa do papiloma-vírus}

As bexigas dos seis animais que vieram a óbito foram analisadas por meio das provas de imunohistoquímica e reação em cadeia pela polimerase.

\section{Imuno-histoquímica}

A pesquisa do papilomavírus, através da técnica de imuno-histoquímica, foi realizada nas seis amostras. O controle positivo reagiu conforme esperado. Não foi possível constatar a presença do antígeno viral em nenhuma das amostras testadas.

\section{Reação em cadeia pela polimerase (PCR)}

A PCR de cortes parafinados foi realizada nos seis animais que vieram a óbito e os resultados se mostraram negativos para BPV- 1 e 2 .

\section{Discussão}

\section{Hematologia:}

Os resultados, bem como a interpretação da análise estatística das cento e quarenta e uma amostras de sangue, das quais setenta e cinco com microhematúria, dezesseis com macrohematúria e cinqüenta amostras dentro dos parâmetros normais, devido à característica intermitente da doença, estão apresentados nas tabelas 1e 2 .

O hematócrito (Ht), neste estudo, dos animais que desenvolveram hematúria clínica variou entre 15\% - $45 \%$, sendo que a média geral ficou em $31 \%$ (Tabela 1). E os animais que apresentaram microhematúria, o Ht variou entre $21 \%$ - 48\%, com média geral de $36 \%$ (Tabela 1). Comparando-se os valores da média geral $31 \%$ e $36 \%$, com os citados em literatura por Schalm et al. (1986) e Coles (1986), verificamos que este se encontra dentro da normalidade. Os valores médios da concentração de hemoglobina $\mathrm{Hb})$ e número de hemácias permaneceram dentro dos valores normais (Tabela 1 ). 
Tabela 1. Valores do eritrograma de bovinos adultos, mestiços nelore, fêmeas, correspondente a 141 amostras, realizadas no período de janeiro a setembro de 1999, nos municípios de Nova Fátima-PR e Sapopema-PR.

\begin{tabular}{|c|c|c|c|c|c|c|c|c|c|c|}
\hline \multirow[b]{2}{*}{ Variável } & \multicolumn{3}{|c|}{ Média } & \multicolumn{3}{|c|}{ Mínimo } & \multicolumn{3}{|c|}{ Máximo } & \multirow{2}{*}{$\begin{array}{l}\text { Desvio } \\
\text { Padrão }\end{array}$} \\
\hline & Micro & Macro & $\overline{\text { Normal }}$ & Micro & Macro & $\overline{\text { Normal }}$ & Micro & Macro & $\overline{\text { Normal }}$ & \\
\hline Ht (\%) & 36 & 31 & 36 & 21 & 15 & 27 & 48 & 45 & 44 & 5,0 \\
\hline $\mathrm{Hb}(\mathrm{g} / \mathrm{dl})$ & 12,45 & 10,41 & 12,48 & 6,90 & 4,80 & 9,50 & 15,10 & 16,60 & 15,40 & 1,8 \\
\hline $\mathrm{He}\left(\times 10^{6} / \mathrm{mm}^{3}\right)$ & 7,53 & 6,65 & 7,58 & 4,41 & 3,78 & 5,67 & 9,24 & 9,45 & 9,24 & 1,0 \\
\hline $\operatorname{VCM}\left(\mu^{3}\right)$ & 47,94 & 46,16 & 47,73 & 41,77 & 26,56 & 38,10 & 53,41 & 48,28 & 48,21 & 2,2 \\
\hline CHCM (\%) & 34,61 & 33,97 & 34,65 & 25,50 & 27,95 & 26,25 & 48,69 & 51,66 & 43,13 & 3,4 \\
\hline HCM (pg) & 16,59 & 15,67 & 16,63 & 12,28 & 9,21 & 12,65 & 23,33 & 24,60 & 20,59 & 1,8 \\
\hline Plaquetas $\left(\times 10^{3} / \mu 1\right)$ & 305,77 & 398,88 & 291,57 & 115,00 & 153,00 & 93,75 & 510,00 & 615,00 & 550,00 & 110,3 \\
\hline Fibrinogênio (mg/dl) & 407,53 & 375,00 & 438,00 & 100,00 & 200,00 & 100,00 & $1.000,00$ & $1.000,00$ & $1.000,00$ & 211,8 \\
\hline
\end{tabular}

Obs: Microhematúria- 75 amostras; Macrohematúria- 16 amostras; Normal: 50 amostras.

Ht:Hematócrito; Hb: Hemglobina; He: Hemácias; VCM: Volume Corpuscular Médio; HCM: Hemoglobina Corpuscular Média; CHCM: Concentração de Hemoglobina Corpuscular Média.

O resultado médio normal do eritrograma encontrado no presente trabalho pode ser explicado pelo fato de que a maioria dos animais estudados encontrava-se na fase de microhematúria (setenta e cinco amostras) e considerando que alguns animais retornaram aos parâmetros urinários normais (cinquenta amostras), pudemos observar que esses animais permaneceram com o eritrograma dentro da normalidade até que desenvolveram a macrohematúria. Estes resultados coincidem com os de Pamukcu, Göksoy e Price (1967), os quais verificaram que em animais com microhematúria não há mudanças hematológicas significativas. Rajendran et al. (1983) relataram que as mudanças hematológicas tornam-se evidentes simultaneamente com o início da macrohematúria e Ghergariu, Bale e Oros (1990), observaram a anemia tanto em animais com microhematúria como em animais com macrohematúria.

Verificou-se que a anemia é progressiva à medida que há um aumento da perda de hemácias íntegras na urina e regride assim que a hematúria cessa. Singh, Joshi e Ray (1972) estudaram animais com macrohematúria e verificaram que há uma considerável redução no hematócrito, hemoglobina e no número de eritrócitos e que a anemia é progressiva devido à perda contínua de hemácias pela urina. O mesmo observaram Jean- Blain, Gastellu e Bringuier (1987) que descreveram que a anemia é devida unicamente a perda de sangue e que essa regride em quinze dias assim que cessa a hematúria.

Os valores médios de volume corpuscular médio (VCM), concentração de hemoglobina corpuscular média (CHCM) e hemoglobina corpuscular média (HCM), permaneceram dentro dos valores normais quando comparados com os citados por Schalm e Jain (1986), devido aos valores normais encontrados para as variáveis $\mathrm{Ht}, \mathrm{Hb}$ e número de eritrócitos.

Em média, a contagem de leucócitos totais, neutrófilos, linfócitos e eosinófilos (Tabela 2), permaneceram dentro dos valores normais quando comparado com Schalm e Jain (1986). Alguns animais apresentaram leucocitose com neutrofilia e linfopenia, representando a agudização do processo, associado a um aumento de hemácias íntegras na urina. Em alguns animais verificamos eosinofilia, fato também observado por Jean-Blain, Gastellu e Bringuier (1987). Tal ocorrência pode ser explicada, segundo Schalm e Jain. (1986), devido a injúria tecidual da mucosa vesical que acarreta a liberação de histamina pelos mastócitos levando a uma eosinofilia e infiltração eosinofílica tecidual. 
Falbo, M. K. et al.

Tabela 2. Valores absolutos do leucograma, de bovinos adultos, mestiços nelore, fêmeas, correspondente a 141 amostras, realizadas no período de janeiro a setembro de 1999, nos municípios de Nova Fátima-PR e Sapopema-PR.

\begin{tabular}{|c|c|c|c|c|c|c|c|c|c|}
\hline \multirow[b]{2}{*}{ Variável } & \multicolumn{3}{|c|}{ Média } & \multicolumn{3}{|c|}{ Mínimo } & \multicolumn{3}{|c|}{ Máximo } \\
\hline & Micro & Macro & Normal & Micro & Macro & Normal & Micro & Macro & Normal \\
\hline Leucócitos/ $\mu \mathrm{l}$ & 11.284 & 9.678 & 11.082 & 5.550 & 5.100 & 5.700 & 25.250 & 14.200 & 17.250 \\
\hline Bastonetes/ $\mu 1$ & 22 & 14 & 16 & 0 & 0 & 0 & 348 & 121 & 179 \\
\hline Segmentados $/ \mu 1$ & 3.182 & 2.645 & 3.109 & 1.080 & 1.053 & 1.083 & 9.000 & 3.664 & 6.233 \\
\hline Eosinófilos/ $\mu 1$ & 1.367 & 1.271 & 1.438 & 282 & 270 & 75 & 5.625 & 2.634 & 2.674 \\
\hline Linfócitos/ $\mu 1$ & 6.680 & 5.742 & 6.495 & 3.385 & 2.397 & 2.535 & 13.382 & 9.994 & 12.367 \\
\hline 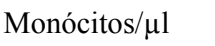 & 25 & 5 & 18 & 0 & 0 & 0 & 484 & 81 & 200 \\
\hline PTP (g/dl) & 9,32 & 8,61 & 9,31 & 7,40 & 7,20 & 7,80 & 10,40 & 10,00 & 10,40 \\
\hline
\end{tabular}

Obs: Microhematúria- 75 amostras; Macrohematúria- 16 amostras; Normal: 50 amostras. PTP: Proteína total plasmática

Não verificamos alterações na média geral para plaquetas (Tabela 1), sendo o mesmo encontrado por Jean-Blain, Gastellu e Bringuier (1987), confirmando que a trombocitopenia e a leucopenia é uma característica somente vista nas intoxicações agudas, e isto pode ser usado, segundo Pamukcu, Göksoy e Price (1967) e Rajendran et al. (1983), como um guia de monitoramento na tentativa de impedir uma intoxicação aguda grave.

Não encontramos alterações significativas para o fibrinogênio, ficando a média geral dentro da normalidade 300 a $700 \mathrm{mg} / \mathrm{dl}$, segundo Schalm e Jain (1986). Não encontramos literatura para comparação destes resultados.

\section{Bioquímica}

Observamos (Tabela 3) que a média geral para o cálcio plasmático tanto na microhematúria $(8,21 \mathrm{mg} /$ dl) como na macrohematúria $(8,38 \mathrm{mg} / \mathrm{dl})$ foi abaixo dos valores normais citados pelos autores (KANEKO; HARVEY; BRUSS, 1997; COLES, 1986; BALARIN, 1990), indicando uma hipocalcemia. Fato este também observado por Singh, Joshi e Ray (1972) em animais com macrohematúria e Ghergariu, Bale e Oros (1990) em animais com macro e microhematúria. O mesmo não foi verificado por Rajendran et al. (1983), que encontraram níveis plasmáticos de cálcio normais.

Tabela 3. Valores das análises bioquímicas, de bovinos adultos, mestiços nelore, fêmeas, correspondente a 141 amostras, realizadas no período de janeiro a setembro de 1999, nos municípios de Nova Fátima-PR e Sapopema-PR.

\begin{tabular}{|c|c|c|c|c|c|c|c|c|c|}
\hline \multirow[b]{2}{*}{ Variável } & \multicolumn{3}{|c|}{ Média } & \multicolumn{3}{|c|}{ Mínimo } & \multicolumn{3}{|c|}{ Máximo } \\
\hline & Micro & Macro & Normal & Micro & Macro & Normal & Micro & Macro & Normal \\
\hline $\mathrm{Ca}(\mathrm{mg} / \mathrm{dl})$ & 8,21 & 8,38 & 8,30 & 3,70 & 5,30 & 5,60 & 11,10 & 10,50 & 10,30 \\
\hline $\mathrm{P}(\mathrm{mg} / \mathrm{dl})$ & 5,57 & 6,61 & 5,43 & 0,30 & 0,40 & 0,20 & 10,50 & 12,40 & 8,90 \\
\hline $\mathrm{Mg}(\mathrm{mg} / \mathrm{dl})$ & 2,28 & 2,28 & 2,20 & 0,60 & 1,20 & 0,20 & 4,70 & 3,50 & 3,30 \\
\hline Creat. (mg/dl) & 1,97 & 2,66 & 1,88 & 0,74 & 1,20 & 0,96 & 3,60 & 9,80 & 3,70 \\
\hline Uréia (mg/dl) & 24,32 & 27,56 & 22,45 & 6,00 & 12,00 & 8,00 & 49,00 & 66,00 & 42,00 \\
\hline Excr. Frac. Ca (\%) & 3,45 & 3,85 & 4,37 & 0,83 & 1,51 & 0,38 & 8,54 & 8,01 & 9,58 \\
\hline Excr. Frac. P (\%) & 1,75 & 1,59 & 2,19 & 0,30 & 0,50 & 0,41 & 6,79 & 3,80 & 7,38 \\
\hline $\mathrm{Ca}-\mathrm{U}(\mathrm{mg} / \mathrm{dl})$ & 6,62 & 6,55 & 6,43 & 0,71 & 1,10 & 1,00 & 14,40 & 13,50 & 13,60 \\
\hline P-U (mg/dl) & 2,08 & 2,06 & 1,94 & 0,40 & 0,50 & 0,10 & 6,90 & 4,00 & 7,40 \\
\hline Creat.-U (mg/dl) & 50,88 & 42,83 & 42,96 & 8,90 & 13,00 & 11,10 & 136,00 & 98,00 & 139,00 \\
\hline
\end{tabular}

Obs: Microhematúria- 75 amostras; Macrohematúria-16 amostras; Normal: 50 amostras. Excr. Frac. Ca: Excreção fracionada de Cálcio;

Excr. Frac. P: Excreção fracionada de Fósforo; Ca-U:Cálcio urinário; P-U: Fósforo urinário; Creat.-U: Creatinina urinária. 
Com relação aos níveis de fósforo e magnésio plasmático, estes se encontraram dentro dos valores normais citados por Coles (1986) e Kaneko, Harvey e Bruss (1997). Achado semelhante a este foram relatados por Rajendran et al. (1983) que obtiveram valores normais para esse eletrólito em um estudo no qual provocava experimentalmente micro e macrohematúria em bezerros. Diferindo dos resultados obtidos pelo presente trabalho, Ghergariu, Bale e Oros (1990) e Singh, Joshi e Ray (1972) verificaram hipofosfatemia e hipomagnesemia.

A análise da excreção fracionada de cálcio foi de $3,45 \%$ para microhematúria e 3,85\% para macrohematúria demonstrando estar acima dos valores obtidos por Balarin (1990), que encontrou o valor de 2,36\% em bovinos fêmeas adultas. Observamos que houve um aumento na excreção desse eletrólito, concordando com as observações de Ghergariu, Bale e Oros (1990) que verificaram hipercalciúria em bovinos com e sem macrohematúria.

Verificamos que a excreção fracionada de fósforo se mostrou aumentada $(1,75 \%)$ para microhematúria e $(1,59 \%)$ para macrohematúria quando comparada com o valor de $0,97 \%$ obtido por Balarin (1990).

Segundo Kaneko, Harvey e Bruss (1997) e Coles (1986), quando há uma hipocalcemia, ocorre liberação do paratormônio (PTH) produzido pelas células secretórias principais da paratireóide que age aumentando a reabsorção renal tubular desse eletrólito e diminuindo a reabsorção tubular de fosfato aumentando assim sua excreção. Tal fato não ocorre para o cálcio, considerando o aumento da excreção desse eletrólito, demonstrando a necessidade de maiores estudos para a determinação das possíveis causas. Já com relação ao fósforo, verificamos que pode estar havendo uma ação hormonal, tendo em vista os resultados apresentados acima. Para tal confirmação seria necessária a determinação dos níveis séricos hormonais o que em princípio não foi objetivo desse trabalho.

A média de $1,97 \mathrm{mg} / \mathrm{dl}$ da creatinina plasmática nas amostras com microhematúria ficou no limite da normalidade justificando o bom funcionamento renal. Kaneko, Harvey e Bruss (1997) cita como valor normal 1-2 mg/dl. Já as amostras dos animais com macrohematúria a média foi de 2,99 mg/dl, semelhante aos achados de Singh, Joshi e Ray (1973) que verificaram que o nível sérico de creatinina aumenta significantemente em animais com hematúria.

A uréia sangüínea apresentou média geral normal tanto para os animais com microhematúria como para as amostras com macrohematúria, que, segundo Kaneko, Harvey e Bruss (1997), é de 20-30 mg/dl. Não encontramos referências bibliográficas para que pudéssemos comparar esse resultado. Oito animais apresentaram níveis plasmáticos aumentados de creatinina e uréia, caracterizando azotemia.

\section{Urinálise}

As análises químicas das amostras de urina (Tabela 4), realizadas através de tiras reagentes, demonstraram moderada proteinúria $(100 \mathrm{mg} / \mathrm{dl})$, apresentando média para as amostras com microhematúria de 63,07 mg/dl e média de 176,25 $\mathrm{mg} / \mathrm{dl}$ para as amostras com macrohematúria. Ghergariu, Bale e Oros (1990) observaram proteinúria moderada tanto em animais com micro como com macrohematúria. Kaneko, Harvey e Bruss (1997) descrevem que é normal encontrarmos uma pequena quantidade de proteína na urina. Quando há proteinúria na presença de eritrócitos e leucócitos a interpretação desse resultado se torna difícil devido à impossibilidade de estabelecer se essa proteinúria é decorrente de uma alteração renal ou se é devido simplesmente à presença dessas células. 
Tabela 4. Valores dos exames físico-químicos e citoscopia da urina em bovinos adultos, mestiços nelore, fêmeas, correspondente a 141 amostras, realizadas no período de janeiro a setembro de 1999, nos municípios de Nova FátimaPR e Sapopema-PR.

\begin{tabular}{|c|c|c|c|c|c|c|c|c|c|}
\hline \multirow[b]{2}{*}{ Variável } & \multicolumn{3}{|c|}{ Média } & \multicolumn{3}{|c|}{ Mínimo } & \multicolumn{3}{|c|}{ Máximo } \\
\hline & Micro & Macro & Normal & Micro & Macro & Normal & Micro & Macro & Normal \\
\hline $\mathrm{pH}$ & 8,6 & 8,8 & 8,5 & 7,0 & 7,5 & 7,0 & 9,0 & 9,0 & 9,0 \\
\hline Proteína (mg/dl) & 63,07 & 176,25 & 19,40 & 0 & 0 & 0 & 500,00 & 500,00 & 100,00 \\
\hline Glicose (mg/dl) & 0 & 0 & 0 & 0 & 0 & 0 & 0 & 0 & 0 \\
\hline Hemoglobinas (mg/dl) & 108,40 & 237,50 & 30,60 & 0 & 50,00 & 0 & 250,00 & 250,00 & 250,00 \\
\hline Cor & 2,2 & 4,0 & 1,6 & 1,0 & 4,0 & 1,0 & 3,0 & 4,0 & 3,0 \\
\hline Aspecto & 2,1 & 3,0 & 1,4 & 1,0 & 3,0 & 1,0 & 3,0 & 3,0 & 3,0 \\
\hline Densidade & 1.019 & 1.017 & 1.015 & 1.000 & 1.002 & 1.000 & 1.038 & 1.030 & 1.037 \\
\hline Leucócitos (x 103/ml) & 5,15 & 6,30 & 0,93 & 0,25 & 0,25 & 0,25 & 189,00 & 48,00 & 8,00 \\
\hline Hemáceas (x 10³/ml) & 351,93 & $3.661,44$ & 1,27 & 5,00 & 19,00 & 0,25 & $3.600,00$ & $10.200,00$ & 4,00 \\
\hline
\end{tabular}

Obs: Microhematúria- 75 amostras; Macrohematúria- 16 amostras; Normal: 50 amostras. Proteína: (+) 30mg/dl; (++) $100 \mathrm{mg} / \mathrm{dl} ;(+++) 500 \mathrm{mg} / \mathrm{dl}$. Hemoglobina: $(+) 10 \mathrm{mg} / \mathrm{dl} ;(++) 50 \mathrm{mg} / \mathrm{dl} ;(+++) 250 \mathrm{mg} / \mathrm{dl}$. Cor: $1=$ amarelo claro; $2=$ amarelo escuro; $3=$ âmbar; $4=$ vermelho. Aspecto: $1=$ límpido; $2=$ ligeiramente turvo; $3=$ turvo

Encontramos através das tiras reagentes valores médios paras as amostras com microhematúria de $108,40 \mathrm{mg} / \mathrm{dl}$ para presença de sangue oculto enquanto que nas amostras com macrohematúria a média encontrada foi de $237,50 \mathrm{mg} / \mathrm{dl}$. Segundo Kaneko, Harvey e Bruss (1997), o método das tiras reagentes para detecção de sangue oculto é altamente sensível e específico. Através do exame do sedimento urinário, pudemos constatar a presença de hemácias e obtivemos como média geral para as amostras com microhematúria de 351.193 hemácias/ml e nas amostras com macrohematúria 3.661.440 hemácias/ $\mathrm{ml}$ indicando anormalidade quando comparada com valores normais padronizados neste estudo $(304,88$ hemácias $/ \mathrm{ml})$.

\section{Anatomia Patológica:}

Diferentes alterações histopatológicas caracterizadas por hiperplasia, metaplasia, inflamações, neoplasia epiteliais e mesenquimais foram verificadas nos animais submetidos ao controle laboratorial. Tais achados são compatíveis com os verificados por Pamukcu, Göskoy e Price (1967); Tokarnia, Döbereiner e Canella (1969); Rajendran et al. (1983) e Jean-Blain, Gastellu e Bringuier (1987).
Durão, Ferreira e Cabral (1995) descrevem as imagens de Brunn que são invaginações epiteliais encontradas na hematúria enzoótica bovina, que foram verificadas também no presente trabalho e coincidentes com focos de hiperplasia e descamação do epitélio.

Um dos bovinos examinados, que no leucograma apresentou eosinofilia, mostrou também em córion de bexiga infiltrado eosinofílico. Tal achado não foi observado por Olson et al. (1959), Olson, Pamukcu e Brobst (1965), Durão, Ferreira e Cabral (1995) e Rajendran et al. (1983), estudando experimentalmente bovinos intoxicados por samambaia, também não verificaram a presença de células eosinofílicas.

Pamukcu, Göskoy e Price (1967), experimentalmente e Jean-Blain, Gastellu e Bringuier (1987), em casos de campo, observaram em animais intoxicados com samambaia a presença de fibroma e mixofibroma. Neste estudo, somente o tipo mesenquimal hemangiomatoso e o carcinoma de células transicionais foram verificados e estão em concordância com as observações realizadas por Durão, Ferreira e Cabral (1995). 
Olson, Pamukcu e Brobst (1965) classificaram como ectásicas as lesões vasculares em bovinos, e atribuíram a lesão a uma possível interação com o vírus do papiloma, em contraposição a todos os materiais de bexiga desta pesquisa, que apresentaram hemangioma ou papilomas e que submetidos às provas de imuno-histoquímica e PCR mostraram reação negativa.

Jarrett et al. (1978) e Pachauri, Sharma e Joshi (1981) sugerem, contudo a possibilidade da etiologia viral para os tumores epiteliais, hemangiomas e fibromas de bexiga dos bovinos.

\section{Imuno-histoquímica e PCR}

A baixa sensibilidade da técnica de imunohistoquímica para detecção de antígenos do gênero Papilomavírus associada ao fato de que em lesões pré-malignas e malignas o genoma viral pode estar integrado ao DNA das células transformadas e desta forma não expressar antígenos estruturais virais (POLACK, 1990), não nos assegura dizer com precisão que o vírus não está associado a essas lesões. Por esse motivo, realizamos a técnica da PCR de cortes parafinados, o qual também nos revelou resultados negativos, sugerindo que nestas amostras o papilomavírus não estava presente. $\mathrm{O}$ emprego desta técnica em um número maior de amostras ou ainda a realização da PCR em tecido sem parafina poderia talvez nos fornecer resultados diferentes.

\section{Conclusão}

Durante o período de estudo pudemos observar:

- Característica intermitente da doença;

- Não houve alteração significativa no eritrograma e leucograma desses animais até que os mesmos desenvolvessem hematúria clínica;

- Hipocalcemia e normofosfatemia;

- Aumento na excreção fracionada de cálcio e fósforo;
- Aumento plasmático de creatinina nos animais com macrohematúria;

- Alterações histopatológicas caracterizadas por hiperplasia, metaplasia, inflamações e neoplasias epiteliais e mesenquimais;

- Não foi possível demonstrar, através da utilização das técnicas imuno-histoquímica e da reação em cadeia pela polimerase a presença do BPV 2 nas lesões de bexiga.

\section{Referências}

BALARIN, M. R. S. Avaliação do estado nutricional de cálcio e fósforo em bovinos por meio da análise bioquímica da urina. 1990. Dissertação (Mestrado) Faculdade de Medicina Veterinária e Zootecnia, Universidade Estadual Paulista "Júlio de Mesquita Filho", Botucatu.

BLOOD, D. C.; RADOSTITS, O. M. Veterinary Medicine. 7.ed. Philadelphia: Baillière Tindall, 1989.

CAMPO, M. S; JARRET, W. F. H; BARRON, R.; O'NEIL, B. W; SMITH, K.T. Association of bovine papillomavírus type 2 and bracken fern with bladder cancer in cattle. Cancer Reserch, Philadelphia, v.52, p.6898-6904, 1992.

CAMPO, M. S.;JARRET, W. F. H.;O'NEIL, W. Latent papillomavirus infection in cattle. Research In Veterinary Science, London, v.56,p.151-157,1994

CAMPO, M. S. Bovine papillomavírus and cancer. The Veterinary Journal, London, v.154, p.175-188, 1997.

CAPLE, I. W.; BOURKET, J. M.; ELLIST, P. G. An examination of the calcium and phosphorus nutrition of throughbred racehorses. Australian Veterinary Journal, Brunswick, v.58, n.4, p.132-135, 1982.

COFFMANN, J. Percent creatinine cleareance rations. Veterinary Medicine and Small Animal Clinician, Bonner Springs, v.75, p.671- 676, 1980.

COLES, E. H. Veterinary clinical pathology. $5^{\text {Th }}$ ed. Philadelphia: W.B. Saunders, 1986.

DURÃO, J. F. C.; FERREIRA, M. L.; CABRAL, A. Aspectos anatomopatológico e clínicos da hematúria enzoótica dos bovinos. Revista Portuguesa de Ciências Veterinárias, Lisboa, v.90, n.515, p.132-137, 1995.

GHERGARIU, S.; BALE, G.; OROS, N. A. Unele modificari hematologice, biochimice sanguine si urinare la taurine intr-o-zona de hematurie enzootica. Revista de Zootehnie Si Medicina Veterinara, Bucuresti, n.5-6, p.15-23, 1990. 
GIMENO, E. J. (Coord.). Octavo curso internacional de posgrado em inmunohistoquimica, lectinhistoquimica y microscopia electronica. La Plata: Universidad Nacional de La Plata, 1997.

HIRONO, I.; FUSHIMI, K; MORI, H. Comparative study of carcinogenic activity in each part of bracken. Journal of National Cancer Institute, Bethesda, v.50, n.5, p.13671371,1973

HOPKINS, N. C. G. Aetiology of enzootic haematuria. Veterinary Record, London, n.118, p.715-717, jun. 1986.

HOPKINS, N. C. G. Enzootic Haematuria in Nepal. Tropical Animal Health and Production, Edinburgh, v.19, p.159164, 1987.

HOPKINS, N. C. G. Bracken ( Pteridium aquilinum): its distribuition and animal health implications. British Veterinary Journal, London, v.146, n.4, p.316-326, 1990.

JARRETT, W. F.H; McNEIL, P. E.; GRIMSHAW, W. T. R.; SELMAN, I. E.; McINTYRE, W. I. M. High incidence area of catle cancer with a possible interaction between an environmental carcinogen and a papilloma virus. Nature, London, v.274, p.215-217, 1978.

JEAN-BLAIN, C.; GASTELlU, J.; BRINGUIER, P. P. Hématurie chronique des bovins: étude clinique. Point Vétérinaire, Maison Alfort, v.19, n.106, p.317-323, 1987.

KANEKO, J. R.; HARVEY, J. W.; BRUSS, M. L. Clinical biochemistry of domestic animals. $5^{\text {th }}$ ed. San Diego: Academic Press, 1997.

LEVINSON, S. A.; McFATE, R. P. Clinical laboratory diagnosis. $7^{\text {th }}$ ed. Philadelphia: Lea \& Febiger, 1969.

MANFIOLETTI, G.; SCHNEIDER, C. A new and fast method for preparing high quality lambda DNA suitable for sequencing. Nucleic Acids Research, Oxford, v.16, n.7, 2873-2884, 1988.

MOURA, J. W; SANTOS, R. C. S; DAGLI, M. L. Z.; DANGELINO, J. L.; BIRGEL, E. H.; BECAK, W. Chromosome aberrations in cattle raised on bracken fern pasture. Experientia, Araraquara, v.44, n.9, p.785-788, 1989.

MURRAY, M. G.; THOMPSON, W. F. Rapid isolation of high molecular weight plant DNA. Nucleic Acids Research, Oxford, v.8, n.19, 4321-4325, 1980

NASIR, L.; McFARLANE, S. T.; TORRONTEGUI, B. O. Screening for bovine papillomavirus in peripheral blood cells of donkeys with and without sarcoids. Research Veterinary Science, London, v.63, p.289- 290, 1997.

NEIGER, R. D.; HAGE MOSER, W. A. Renal percent cleareance ratios in cattle. Veterinary Clinical Pathology, Santa Barbara (California), v.14, n.1, p.31-35, 1985.
OLSON, C.; PAMUKCU, A. M.; BROBST, D.F.; KOWALCZYK, T.; SATTER, E. J.; PRICE, J. M.

A urinary bladder tumor induced by a bovine cutaneous papilloma agent. Cancer Research, Philadelphia, v.19, n.7, p.779-783, 1959.

OLSON, C.; PAMUKCU, A. M.; BROBST, D. F. Papillomalike virus from bovine urinary bladder tumors. Cancer Reserch, Philadelphia, v.25, p.840-849, 1965.

PACHAURI, S. P.; SHARMA, U. K.; JOSHI, H. C. Note on pathological studies on the urinary bladder tumors of cattle with chronic haematurie. Indian Journal of Veterinary Science, New Delhi, v.51, n.9, p.898-900, 1981.

PAMUKCU, A. M.; GÖKSOY, S. K.; PRICE, J. M. Urinary bladder neoplasms induced by feeding bracken fern ( Pteris aquilina ) to cows. Cancer Research, Philadelphia, v.27, p.917-924, 1967.

POLACK, E. W. Toxicidade da Pteridium aquilinum (L.) Kühn no Estado do Paraná Curitiba. 1990. Dissertação ( Mestrado ) - Universidade Federal do Paraná, Curitiba.

RAJENDRAN, M. P.; CHENNAKESAVALU, M.; NARAYANA RAO, C. V.; VIRAGHAVAN, K.; DAMODARAM, S. Experimental production of enzootic bovine haematuria with bracken fern. Indian Journal of Veterinary Science, New Delhi, v.60, n.3, p.173-178, 1983.

SCHALM, O. M.; JAIN, N. C. Veterinary Hematology. $4^{\text {th }}$ ed. Philadelphia: Lea \& Fabiger, 1986.

SINGH, A.K.; JOSHI, H. C.; RAY, S. N. Studies on bovine haematuria. I. Haematological and biochemical observations on the blood of catlle suffering from haematuria. Indian F. Animal Science, Penicuik, v. 43, n.4, p.296-299, 1972.

TOKARNIA, C. H.; DÖBEREINER, J.; CANELLA, C. F. C. Ocorrência da Hematúria Enzoótica e de carcinomas epidermóides no trato digestivo superior em bovinos no Brasil. II. Estudos complementares. Pesquisa Agropecuária Brasileira, Brasília, v.4, p.209-224, 1969.

TOKARNIA, C. H.; DÖBEREINER, J.; SILVA, M. Plantas tóxicas da Amazônia a bovinos e outros herbívoros. Manaus: Instituto Nacional de Pesquisas da Amazônia, 1979.

TUKEY, J. W. Exploratory data analysis. $3^{\text {rd }}$ ed. Reading: Addison- Wesley, 1977.

VALLADA, E. P. Exame quantitativo do sedimento urinário. In: Manual de exames de urina. 3.ed. Rio de Janeiro: Atheneu, 1981. Cap.6, p.89-95.

YOSHIKAWA, T.; OYAMADA, T. Histopathology of papillary tumors in the bovine urinary bladder. Japanese Journal of Veterinary Science, Tokyo, v.37, p.277-287, 1975. 